\title{
The Neuropathology of Genetic Parkinson's Disease
}

\author{
M Poulopoulos, MD ${ }^{1}$, OA Levy, MD, $\mathrm{PhD}^{1}$, and RN Alcalay, MD MSc ${ }^{1,2}$ \\ ${ }^{1}$ Department of Neurology, College of Physicians and Surgeons, Columbia University, New York, \\ NY, USA \\ ${ }^{2}$ Taub Institute for Research on Alzheimer's Disease and the Aging Brain, College of Physicians \\ and Surgeons, Columbia University, New York, NY, USA
}

\begin{abstract}
Background-Pathological data from autopsies genotyped for PD-related mutations in alphasynuclein, Parkin, PINK1, DJ1, LRRK2 and glucocerebrosidase have accumulated in recent years. The aim of this review is to systematically review all pathological reports of mutation carriers and to identify pathological patterns and gaps in the currently available data.
\end{abstract}

Methods-A systematic review of the English literature using the terms "Parkinson's disease", "brain pathology", "autopsy", and the specific gene nomenclature, and any combination of the above.

Results-Most studies included reports of convenience samples, either cases that were preidentified as mutation carriers before autopsy, or screens of Lewy body brain banks. Nineteen autopsies of alpha-synuclein mutation carriers, 49 of LRRK2 mutation carriers, 9 of Parkin mutation carriers, one of PINK1 mutation carrier and 90 of glucocerebrosidase mutation carriers were identified. Most autopsies of alpha-synuclein, LRRK2 G2019S and glucocerebrosidase mutation carriers demonstrated Lewy body pathology as opposed to Parkin and $L R R K 2$ nonG2019S mutation carriers. However, there was a marked variability in pathological findings even among carriers of identical mutations. Pathological data from $D J 1$ mutation carriers, nonmanifesting mutation carriers (e.g., of $L R R K 2$ mutations), and carriers of a single Parkin mutation were lacking.

Discussion-In gathering together all studies of PD autopsies with an identified genetic risk, this review highlights the wealth of information generated, as well as shortcomings in the available data. In particular, there is a need for larger, unbiased pathological studies. Differential association of Lewy pathology with specific mutations may reflect heterogeneity in pathogenic mechanisms among the different PD-related genes.

\section{Introduction}

Parkinson's disease (PD) is the second most common neurodegenerative disease. ${ }^{1-2} \mathrm{PD}$ is a complex disorder which is probably caused by interactions between genetic and environmental risk factors. However, a subset of people affected by PD carries a genetic risk factor that is associated with the disease. ${ }^{3}$ Different genetic risk factors carry varying degrees of risk for PD. The penetrance of alpha-synuclein $(S N C A)$ triplications and point

Corresponding author: Roy N. Alcalay, 710 West $168^{\text {th }}$ Street, New York City, New York., Phone: 212-305-5554. rna2104@columbia.edu.

These authors contributed equally to this work

Authorship contribution: Manuscript drafting: Drs. Poulopoulos, Levy and Alcalay

Disclosure: The authors report no conflicts of interest.

Drs. Poulopoulos has nothing to disclose. 
mutations, and Parkin, PINK-1 and DJ-1 homozygote or compound heterozygote mutations is estimated to be very high. $S N C A$ duplications and $L R R K 2$ mutations have incomplete penetrance. Glucocerebrosidase (either heterozygous or homozygous) mutations convey a risk for PD, and the role of heterozygous mutations in Parkin, PINK-1 and DJ-1 in the pathogenesis of PD is controversial. The discovery of genetic forms of PD provides insight to its pathogenesis and allows researchers to develop genetic animal models that may more closely replicate PD. ${ }^{4}$

In spite of advances in clinical and imaging diagnostic approaches, pathological confirmation is still considered the gold standard in the diagnosis of PD. The pathologic hallmark of PD is the loss of dopamine producing neurons in the substantia nigra pars compacta (SNpc) accompanied by the intraneuronal accumulation of alpha-synuclein containing Lewy bodies (LBs) and Lewy neurites (LNs) resulting in dopamine deficiency. ${ }^{5-6}$

While mutation carriers are often clinically indistinguishable from patients with idiopathic PD (iPD), neuropathological findings can be markedly different. The potential association between consistent pathological findings and specific genetic mutations may help elucidate the pathogenetic mechanisms of neurodegeneration in PD mutation carriers. In this review, we searched the literature, using the PubMed and Scopus search engines, using the terms "Parkinson's disease", "brain pathology", "autopsy", the specific gene nomenclature, and any combination of the above. Our goal was to summarize the pathological findings for each mutation and identify patterns of degeneration linked to specific gene alterations.

\section{PARK1/4 (alpha-synuclein - SNCA gene)}

SNCA gene point mutations ( $\mathrm{A} 53 \mathrm{~T}^{7}, \mathrm{~A} 30 \mathrm{P}^{8}$ and $\mathrm{E} 46 \mathrm{~K}^{9}$ ), assigned as PARK1, as well as duplications ${ }^{10}$ and triplications ${ }^{11}$ (PARK4) cause autosomal dominant PD with variable penetrance. Penetrance in duplication carriers ranges between $30 \%$ and $50 \%$, whereas triplication and point mutation carriers show nearly complete penetrance. ${ }^{12-13}$

Clinically, carriers may have rapid motor progression and frequent dementia. Triplications result in earlier onset of PD and dementia, whereas duplication carriers tend to develop lateronset PD with dysautonomia, although the phenotype can be variable. ${ }^{14}$

Thirteen studies reported on 19 autopsies of carriers of $S N C A$ gene mutations and multiplications, all with a clinical diagnosis of PD (table 1). Six studies analyzed PARK1 carriers $9,15-19$ and seven studies PARK4 cases with PD. ${ }^{20-26}$ Nine of the 13 studies screened only familial PD cases with known genotype. Four of the studies also analyzed participants without familial PD, including 42 controls, ${ }^{19}, 21-22,26$ eight sporadic PD, ${ }^{21}, 26$ three dementia with LBs (DLB), ${ }^{22} 12$ Alzheimer's disease (AD) ${ }^{21}$ and one patient with multiple system atrophy (MSA) ${ }^{22}$; none of these were reported as mutation carriers.

In addition, two other studies screened exclusively brain tissue of 50 MSA patients and eight controls for $S N C A$ gene mutations; none carried a mutation. ${ }^{27-28}$

Overall, the pathological features of PARK1 and PARK 4 mutation carriers with PD phenotype had a common pattern. All 19 autopsies showed alpha-synuclein containing neurons in the form of LBs and LNs. Five of the cases had alpha-synuclein inclusions within oligodendroglia, reminiscent of the glial cytoplasmic inclusions seen in MSA. ${ }^{18-19,} 22,24$ The neuronal loss was more severe in the brainstem, particularly in SNpc and LC. Nevertheless, it frequently involved cortical areas with a propensity for the hippocampal formation (13 out of 19 cases affected), particularly in CA2/3. Cortical neuronal loss may explain clinical dementia that was observed in all patients. In addition, neurofibrillary 
tangles (NFTs) were present in a variable distribution in 9 out of 17 autopsies in which tau immunohistochemistry was reported. The density of tau inclusions was too low to qualify for pathological diagnosis of AD. ${ }^{29-30}$ Interestingly, 2/17 (1 A53T, ${ }^{16} 1$ triplication $^{22}$ ) cases showed inclusions with both tau and alpha-synuclein immunostaining, an unusual finding in PD. In addition, one case (A53T) showed TDP-43 inclusions in neurites and cell bodies in the temporal cortex, in a pattern consistent with FTLD. ${ }^{18}$. In summary, all SNCA associated autopsies report alpha synuclein pathology. However, most cases were not pure synucleinopathies, since tau inclusions were frequent. In addition, relatively few control brains were screened for these mutations.

\section{PARK 8 (leucine-rich repeat kinase 2 - LRRK2)}

$L R R K 2$ is a common genetic cause of PD. The G2019S mutation is the most common mutation worldwide, ${ }^{31}$ and the $\mathrm{G} 2385 \mathrm{R}$ variant is a common risk factor in Asian populations. ${ }^{32}$ The International LRRK2 Consortium study estimated that the G2019S mutation accounts for $1 \%$ of sporadic and $4 \%$ of familial PD patients. The highest frequency was found in North African Arabs (36\% in familial, 39\% in sporadic) and Ashkenazi Jews (28\% and 10\% respectively). Penetrance estimates are age-dependent and widely variable, ranging between 30 and $74 \% .31,33$ The clinical phenotype is similar to idiopathic PD. 31

The neuropathology of various $L R R K 2$ mutations is heterogeneous. Forty nine autopsy reports of $L R R K 2$ mutation carriers have been reported including $28 \mathrm{G} 2019 \mathrm{~S}$ mutation carriers (25 with parkinsonism from ten studies, ${ }^{34-43}$ one with FTLD, one with AD and one control) and 21 PD patients with other $L R R K 2$ mutations from ten studies. ${ }^{35,44-52}$

Of the ten studies reporting on G2019S carriers, five studies screened a total of 891 patients with LB disorders, ${ }^{34-35,37-39} 363$ progressive supranuclear palsy (PSP), ${ }^{35,}{ }^{37-38} 62$ MSA, ${ }^{35,37-38}$ seven corticobasal degeneration (CBD), 35,3740 essential tremor (ET), ${ }^{37,53}$ $654 \mathrm{AD},{ }^{38} 59$ FTLD, ${ }^{35,37,42} 102$ Huntington disease (HD) ${ }^{34}$ and 444 controls. ${ }^{37-38,41}$ Of these control and non-PD neurodegenerative cases, one with FTLD, ${ }^{42}$ one with AD and one control were found to have the G2019S mutant. ${ }^{38}$ The remaining studies analyzed PD patients with known genotype.

Most autopsy studies on 21 mutation carriers other than G2019S screened only PD patients. However, there is one study that examined brain tissue of 242 PSP patients for mutations at the R1441 residue ${ }^{54}$ and another that screened for LRRK2 mutations (G2019S, I2020T, $\mathrm{R} 1441 \mathrm{C}$ and $\mathrm{Y} 1699 \mathrm{C}$ ) in 24 ET brains ${ }^{53}$; none was a mutation carrier.

Overall, in G2019S mutation carriers with parkinsonism neuronal loss in the SNpc and LC was universal. LB pathology was the most common finding in G2019S brains in $79 \%$ (22 of 28 ); the extent of cortical involvement was variable (table 2). Tau-inclusions were present in a variable distribution and severity in 22 out of the 28 reports (including the cases of AD and PSP like changes with a G2019S mutation). Clinically, dementia was infrequently reported (8 out of 28). Carriers of mutations other than G2019S (see Table 2 for specific mutations studied) were more likely to have more neuronal loss in the SNpc than the LC and less likely to have LBs, which were present only in 43\% (9 out of 21). TDP-43-positive inclusions were identified in 3 cases: 1 patient each with R793M and L1156P in temporal cortex, ${ }^{51}$ and 1 patient with $\mathrm{R} 1441 \mathrm{C}$ in the substantia nigra. ${ }^{55}$ The overall frequency of this finding is unclear since most series did not include TDP-43 immunostaining. Dementia was reported in only two out of 21 cases (table 2). No G2385R-related PD autopsies have been reported to date. 
In summary, pathological features of different $L R R K 2$ mutations may vary considerably. The majority of G2019S carriers with PD had LB containing neurons as opposed to the other $L R R K 2$ mutations. Therefore, it may be implied from the pathological findings that the pathogenesis of PD in LRRK2 mutation carriers is variable, depending at least partially upon the specific mutation. In addition, there are other factors involved, since patients with identical $L R R K 2$ mutations (even those in the same family) can have widely variable pathology. ${ }^{46}$

\section{PARK2 - Parkin}

Homozygous and compound heterozygous Parkin mutations are established risk factors for early-onset PD (EOPD) world-wide. ${ }^{56}$ Patients were described to have sleep benefit, dystonia, hyperreflexia and good response to levodopa with high likelihood to develop dyskinesias. ${ }^{57}$ Older age at onset has been described ${ }^{58}$ Mutations may be more common in Hispanics with EOPD. ${ }^{59-60}$ Parkin dosage mutations are likely more pathogenic than point mutations. However, the role of heterozygous Parkin mutations in the pathogenesis of PD remains controversial. ${ }^{61}$. Two brain autopsies from autosomal recessive juvenile parkinsonism cases in Japan (later linked to 6q25.2-2762) showed neuronal loss in SNpc and LC without LBs. ${ }^{63}$ There are nine autopsy reports of patients with homozygous or compound heterozygous Parkin mutations. Six of the nine reports derived from either cases that were known Parkin mutations carriers before autopsy or from screening familial PD cases. Three studies screened brain banks, including 350 PD patients and 342 controls. ${ }^{64-66}$ None of the control brains carried Parkin mutations. To our knowledge, no large brain bank screens of other neurodegenerative diseases for Parkin mutations have been reported.

Of the nine cases, six had SNpc neuronal loss with no LB pathology, 65, 67-71 two had typical $\mathrm{LBs}^{64,72}$ and one had basophilic LB-like inclusions in the pedunculopontine nucleus (PPN) and eosinophilic LB-like inclusions in the anterior horn cells of the lumbar spinal cord. ${ }^{66,73}$ All, but the two with typical LBs, showed more neuronal loss in the SNpc than the LC (in contrast to iPD). Tau inclusions were present in two out of nine autopsies (table 3).

There is only one case report of an autopsy on a heterozygous Parkin mutation carrier. This patient had a clinical and pathological diagnosis of PSP. Three of his six sons have clinical EOPD and are compound heterozygotes for Parkin mutations. ${ }^{74}$

In summary, the majority of the Parkin autopsies are not associated with alpha-synuclein neuronal inclusions. Unlike iPD, most reports had significantly more involvement of the SN than the LC. However, even in this presumably homogeneous genetic group there was variability, since some cases had LB pathology and tau inclusions. The small number of cases precludes any definite association between the type of Parkin mutation and the presence of alpha-synuclein pathology. Data on heterozygous Parkin carriers with PD are lacking, as no autopsy of Parkin heterozygotes with PD has been reported. Given the later age-at-onset among heterozygotes ${ }^{59}$ and their olfactory impairment, ${ }^{75}$ it is possible that heterozygous mutation carriers have different brain pathology from homozygotes or compound heterozygotes. Alternatively, Parkin heterozygosity may not be a risk factor for $\mathrm{PD}$ and thus have no bearing on pathology.

\section{PARK6 - PTEN-induced putative kinase 1 (PINK1)}

PINK1 is a cause of early-onset PD. ${ }^{76}$ The phenotype can be similar to Parkin mutation carriers, although PINK1 carriers may be prone to psychiatric co-morbidity and present with gait disturbance. ${ }^{77-78}$ 
Only one brain autopsy of a compound heterozygote for a deletion and a splicing mutation in exon 7 has been described. He developed PD at age 31 and florid psychosis 6 years later. Disease duration was eight years. Autopsy findings were significant for LB pathology and neuronal loss in the SNpc sparing the LC, which would be atypical for iPD. The brainstem reticular formation and the nbM were also involved. No tau- or TDP43-positive inclusions were observed. ${ }^{78}$

As in Parkin, the role of heterozygous PINK 1 mutations is controversial. ${ }^{79}$ In a PD brain bank study, extensive screening (number not reported) for PINK1 mutations revealed four heterozygotes with the following mutations: A339T, Y431H, N451S and C575R. ${ }^{80}$ They all had clinical and pathological PD with psychiatric features and negative family history. Two had cognitive impairment, one of whom had AD pathology. On autopsy, all heterozygous PINK1 carriers showed the typical PD distribution of brainstem and cortical LBs, with SNpc neuronal loss and NFT stage from I to V. The investigators co-studied two controls, eight PD, two DLB, two MSA, two PSP, two CBD and two AD cases.

In summary, data on pathological changes in PINK1 mutation carriers is very limited. However, the one PINK1 mutation carrier who reached autopsy had LB pathology. Therefore, there are no pathological correlates to the hypothesis that PINK1 and Parkin are involved in similar pathways in the pathogenesis of PD.

\section{PARK7 - DJ-1}

PARK 7 mutations are a rare cause of EOPD, described in Dutch, Italian and Uruguayan families. ${ }^{81-82}$ It accounts for less than to $1 \%$ of early-onset parkinsonism. ${ }^{83}$ The phenotype can vary from slow onset and good response to levodopa to encompass dystonic and psychiatric features, ${ }^{82}$ as well as motor neuron disease with dementia. ${ }^{84}$ There are no published autopsies of $D J-1$ mutation carriers. However, there are no negative reports of large brain bank screening either.

\section{Glucocerebrosidase (GBA)}

Homozygous mutations in the gene encoding the lysosomal enzyme glucocerebrosidase $(G B A)$ lead to Gaucher disease (GD), the most common autosomal recessive lysosomal storage disease. About 300 mutations in $G B A$ have been reported. ${ }^{85}$ Several patients with GD have been reported with parkinsonism, some with typical appearing PD. ${ }^{86}$ Following on this observation, several groups have found that heterozygous $G B A$ mutation carriers (i.e. without GD) are at increased risk of developing PD, especially in the Ashkenazi Jewish (AJ) population, although other ethnicities are also affected. ${ }^{87}$ Clinically, $G B A$ heterozygotes may be indistinguishable from iPD. However, they may have earlier age at onset, more prevalent cognitive impairment and may not respond to levodopa as well as in iPD. ${ }^{88-89}$

Ten autopsies of GD patients with parkinsonism were reported from studies on cases with known pre-mortem diagnosis $90-92$ and from one brain bank screening on PD patients blinded to the pre-mortem diagnosis. ${ }^{93}$ In the latter study, two GD out of 57 PD patients (3.5\%) were found and none in 44 controls. Collectively, all autopsies had LBs; five with transitional/diffuse, one with brainstem-predominant distribution and no details reported in four cases. Neuronal loss was documented in the SNpc in all cases. However, GD autopsies with no LB pathology have been reported in patients without clinical parkinsonism. ${ }^{89,91}$ Prominent gliosis and mild neuronal loss was observed in the CA2-4 layers of the hippocampal formation, calcarine layer $4 \mathrm{~b}$ and fifth layer of the cerebral cortex. ${ }^{93}$ When the characteristic Gaucher pathological features were sought in these autopsies, Gaucher cells were found in all four brains in one study, ${ }^{91} \mathrm{LBs}$ stained for $G B A$ antibodies in all three in another ${ }^{92}$ and enzyme activity ranged from $7-11 \%$ in both cases 
studied specifically. ${ }^{93}$ However, in one study, all four cases showed the same brain glucosylsphingosine (a toxic metabolite that is elevated in the brain of those with neuronopathic GD) levels as controls..$^{90}$ Other pathology, such as tau-inclusions, was not reported.

In addition, 80 autopsies of $G B A$ heterozygotes have been described in 11 studies. ${ }^{53,89,92-100}$ All autopsies were obtained from brain bank screens without knowledge of the genetic or clinical information, apart from one study. ${ }^{92}$ Four of 11 studies examined degenerative diseases other than PD and DLB. ${ }^{53}, 89,97,100$ Overall, a total of 843 PD/ DLB ${ }^{89,}, 92-9924 \mathrm{ET},{ }^{53} 60 \mathrm{AD},{ }^{89} 120 \mathrm{MSA}^{97,} 100$ and 317 control $^{89-90,93,95-96}$ autopsies were analyzed. Of these, mutations and variants were found in 80 PD/DLB (9.5\%), six AD $(10 \%)$ two ET $(8 \%)$ and one MSA $(0.8 \%)$ as well as four of 317 controls $(1.3 \%)$. The frequency of $G B A$ heterozygotes in PD patients ranged from 3.5\% (1 of 29) ${ }^{97}$ and $4.5 \%$ (17 of 380$)^{96}$ to $10.5 \%$ (6 of 57). ${ }^{93}$ Most studies did not stratify their findings by AJ ancestry. Among DLB autopsies, mutation status varied from $6 \%(3 \text { of } 50 \text { DLB })^{95}$ in non-AJ population to $23 \%$ ( 8 of 35$)^{97}$ and $27.5 \%$ (26 of 95$)^{89}$ in brain bank studies that included AJ patients. All three larger brain bank screens - including the studies from NIH/University of Pennsylvania, ${ }^{97}$ Columbia University ${ }^{89}$ and Queen Square Brain Bank ${ }^{96}$ - reported that $G B A$ mutation status was associated with widespread cortical LBs. However, the latter group retracted this statement after re-studying the $17 \mathrm{PD} G B A$ heterozygous carriers and 16 PD controls and adjusting for confounding variables. ${ }^{101}$ In addition, the Columbia group reported an association of the $\mathrm{E} 326 \mathrm{~K}$ and $\mathrm{T} 369 \mathrm{M}$ variants with $\mathrm{PD},{ }^{89}$ even though the pathogenicity of these variants has not been clearly demonstrated in GD. The association between these variants and PD was corroborated in studies including familial and sporadic PD patients. ${ }^{102-103}$

On pathology, 77 of $80 G B A$ heterozygotes with parkinsonism had LB-containing neurons. The distribution involved cortical areas in 78 of 80 patients, according to the third report of the DLB consortium. ${ }^{104}$ Most studies did not report in detail the neuronal loss distribution. In the five studies reporting on additional pathology, co-existent AD was present in 11 out of 55 cases (table 4 ).

In summary, $G B A$ mutations are a common risk factor for $\mathrm{PD}$, especially among Ashkenazi Jews. Nearly all PD patients who were $G B A$ mutation carriers had LB pathology. However, consistent with estimated incomplete penetrance, control brains with $G B A$ mutations have been reported as well. Further research is underway to test the hypothesis that $G B A$ mutations are linked to cortical LBs in patients with clinical PD.

\section{DISCUSSION}

In this review, we have compiled all of the published autopsy data on PD patients with identified genetic mutations. The data are summarized below (table 5).

There were limitations of the published studies. First of all, the majority of these studies analyzed PD or DLB populations. Only a minority screened a variety of neurodegenerative diseases and controls deriving from brain bank data. This issue was particularly relevant for SNCA, Parkin and non-G2019S LRRK2 mutations. Second, the studies were not homogeneous with regard to the protocol followed or the ethnic background of the population studied. Third, the number of autopsies is small overall, with the exception of $G B A$ mutation carriers. In particular, there are no reports on $D J-1$ mutations carriers or Parkin heterozygotes. Similarly, there is only one PINK1 compound heterozygous mutation carrier who came to autopsy. Thus, the evidence from the reported autopsies may not represent the full pathological spectrum of a specific mutation. For example, while in vitro 
studies implicate Parkin and PINK-1 in the same mitochondrial pathway, most Parkin autopsies have no LBs while the single reported PINK-1 autopsy has LB pathology. Furthermore, most genetic risks for PD are not associated with complete penetrance. Ideally, large autopsy studies would have been able to provide a more accurate estimate of association between possible risk factors (e.g. Parkin heterozygosity) and PD pathology, as some mutation carriers may have subclinical pathological involvement. However, given the high cost, very few studies of control autopsies have been performed. Another complicating issue is that of phenocopies, i.e. mutation-negative family members with PD phenotype. These have been described for SNCA, LRRK2, Parkin, and PINK-1 families; to date, none of these have reached autopsy. ${ }^{105}$ Fourth, many of the current studies did not include a detailed description of the neuronal loss distribution. The degree of neuronal loss is important since it is more likely to correlate with clinical features than the presence and distribution of LBs, as up to $50 \%$ of cases with widespread LB pathology can be asymptomatic during life. ${ }^{106}$ Fifth, additional pathologic inclusions were inconsistently reported. There is still the question of whether or not the formation of LBs and tau inclusions could share a common pathogenesis, as up to $40 \%$ of iPD may have coexistent $\mathrm{AD}$ pathology. ${ }^{107}$ The frequent finding of tau inclusions in PD-mutation carriers, particularly those with LB pathology, supports the hypothesis of a mechanistic relation, assuming that the disease is caused by a single mutation. Other evidence also supports a link between aggregation of tau and alpha-synuclein, such as their co-localization in the brain of an A53T SNCA mutation carrier, ${ }^{16}$ and the LRRK2 immunostaining of LBs and tau inclusions in AD, FTLD and Pick's disease brain samples. ${ }^{108}$ TDP-43 inclusions are most commonly associated with FTLD-U and ALS. One study found that 5/69 (7\%) of PD and $4 / 21$ (19\%) of PDD cases were positive for TDP-43 inclusions (the genotypes of these cases is unknown). ${ }^{109}$ Our review identified 4 cases (1 SNCA, 3 LRRK2) with TDP-43 inclusions. However, it should be noted that many of the studies in our review were performed prior to the identification of TDP-43. The potential interaction between alpha-synculein and TDP-43, especially in genetic forms of PD, warrants additional work.

There is a striking difference in the association with LB pathology among the different gene mutations. LBs are seen in all mutant $S N C A$ patients, nearly all $G B A$ carriers, and most LRRK2 G2019S patients. Therefore, animal models based on these mutations may more closely recapitulate the pathogenic mechanisms involved in synucleinopathies. On the other hand, the majority of the Parkin and $L R R K 2$ non-G2019S mutation carriers did not have LB pathology. This raises the issue of relying on the presence of $\mathrm{LB}$ for the diagnosis of PD. ${ }^{110}$ Alternative criteria based on SN neuronal loss may be more inclusive.

Clearly, there is a need for comprehensive studies with a focus on brain bank screening for the PD-related mutations in patients with various neurodegenerative diseases and controls. Such an undertaking would enable us to acquire a more accurate estimate of the penetrance of these mutations and elucidate a possible correlation between specific mutations and patterns of degeneration in PD and, possibly, other neurodegenerative diseases. In order to achieve this goal, a systematic mechanism of obtaining, storing, processing and reporting autopsy findings (e.g., the common data elements proposed by the NINDS) is required.

\title{
Acknowledgments
}

\author{
Dr. Poulopoulos is a Parkinson's Disease Foundation fellow. RNA is supported by the Brookdale Foundation \\ Leadership in Aging Fellowship. \\ Dr. Levy is supported by the NIH (K08NS070608) and the Smart Foundation.
}

Dr. Alcalay is funded by the Brookdale Foundation, the Smart Foundation, the Michael J Fox Foundation and the Parkisnon's Disease Foundation. 


\section{REFERENCES}

1. Hirtz D, Thurman DJ, Gwinn-Hardy K, Mohamed M, Chaudhuri AR, Zalutsky R. How common are the "common" neurologic disorders. Neurology. 2007; 68:326-337. [PubMed: 17261678]

2. Elbaz A, Bower JH, Maraganore DM, et al. Risk tables for parkinsonism and Parkinson's disease. J Clin Epidemiol. 2002; 55:25-31. [PubMed: 11781119]

3. Gasser T. Update on the genetics of Parkinson's disease. Mov Disord. 2007; 22(Suppl 17):S343S350. [PubMed: 18175395]

4. Li Y, Liu W, Oo TF, et al. Mutant LRRK2(R1441G) BAC transgenic mice recapitulate cardinal features of Parkinson's disease. Nature neuroscience. 2009; 12:826-828.

5. Braak H, Del Tredici K, Rub U, de Vos RA, Jansen Steur EN, Braak E. Staging of brain pathology related to sporadic Parkinson's disease. Neurobiol Aging. 2003; 24:197-211. [PubMed: 12498954]

6. Daniel SE, Lees AJ. Parkinson's Disease Society Brain Bank, London: overview and research. Journal of neural transmission Supplementum. 1993; 39:165-172. [PubMed: 8360656]

7. Polymeropoulos MH, Lavedan C, Leroy E, et al. Mutation in the alpha-synuclein gene identified in families with Parkinson's disease. Science. 1997; 276:2045-2047. [PubMed: 9197268]

8. Kruger R, Kuhn W, Muller T, et al. Ala30Pro mutation in the gene encoding alpha-synuclein in Parkinson's disease. Nat Genet. 1998; 18:106-108. [PubMed: 9462735]

9. Zarranz JJ, Alegre J, Gomez-Esteban JC, et al. The new mutation, E46K, of alpha-synuclein causes Parkinson and Lewy body dementia. Ann Neurol. 2004; 55:164-173. [PubMed: 14755719]

10. Ibanez P, Bonnet AM, Debarges B, et al. Causal relation between alpha-synuclein gene duplication and familial Parkinson's disease. Lancet. 2004; 364:1169-1171. [PubMed: 15451225]

11. Singleton AB, Farrer M, Johnson J, et al. alpha-Synuclein locus triplication causes Parkinson's disease. Science. 2003; 302:841. [PubMed: 14593171]

12. Nishioka K, Hayashi S, Farrer MJ, et al. Clinical heterogeneity of alpha-synuclein gene duplication in Parkinson's disease. Annals of neurology. 2006; 59:298-309. [PubMed: 16358335]

13. Ahn TB, Kim SY, Kim JY, et al. alpha-Synuclein gene duplication is present in sporadic Parkinson disease. Neurology. 2008; 70:43-49. [PubMed: 17625105]

14. Wilson HD, Boyette-Davis J, Fuchs PN. The relationship between basal level of anxiety and the affective response to inflammation. Physiol Behav. 2007; 90:506-511. [PubMed: 17174362]

15. Golbe LI, Di Iorio G, Bonavita V, Miller DC, Duvoisin RC. A large kindred with autosomal dominant Parkinson's disease. Ann Neurol. 1990; 27:276-282. [PubMed: 2158268]

16. Duda JE, Giasson BI, Mabon ME, et al. Concurrence of alpha-synuclein and tau brain pathology in the Contursi kindred. Acta Neuropathol. 2002; 104:7-11. [PubMed: 12070658]

17. Spira PJ, Sharpe DM, Halliday G, Cavanagh J, Nicholson GA. Clinical and pathological features of a Parkinsonian syndrome in a family with an Ala53Thr alpha-synuclein mutation. Annals of neurology. 2001; 49:313-319. [PubMed: 11261505]

18. Markopoulou K, Dickson DW, McComb RD, et al. Clinical, neuropathological and genotypic variability in SNCA A53T familial Parkinson's disease. Variability in familial Parkinson's disease. Acta neuropathologica. 2008; 116:25-35.

19. Seidel K, Schols L, Nuber S, et al. First appraisal of brain pathology owing to A30P mutant alphasynuclein. Annals of neurology. 2010; 67:684-689. [PubMed: 20437567]

20. Waters $\mathrm{CH}$, Miller CA. Autosomal dominant Lewy body parkinsonism in a four-generation family. Ann Neurol. 1994; 35:59-64. [PubMed: 8285594]

21. Muenter MD, Forno LS, Hornykiewicz O, et al. Hereditary form of parkinsonism--dementia. Annals of neurology. 1998; 43:768-781. [PubMed: 9629847]

22. Gwinn-Hardy K, Mehta ND, Farrer M, et al. Distinctive neuropathology revealed by alphasynuclein antibodies in hereditary parkinsonism and dementia linked to chromosome $4 \mathrm{p}$. Acta neuropathologica. 2000; 99:663-672. [PubMed: 10867800]

23. Wakabayashi K, Hayashi S, Ishikawa A, et al. Autosomal dominant diffuse Lewy body disease. Acta neuropathologica. 1998; 96:207-210. [PubMed: 9705138]

24. Obi T, Nishioka K, Ross OA, et al. Clinicopathologic study of a SNCA gene duplication patient with Parkinson disease and dementia. Neurology. 2008; 70:238-241. [PubMed: 18195271] 
25. Ikeuchi T, Kakita A, Shiga A, et al. Patients homozygous and heterozygous for SNCA duplication in a family with parkinsonism and dementia. Archives of neurology. 2008; 65:514-519. [PubMed: 18413475]

26. Farrer M, Kachergus J, Forno L, et al. Comparison of kindreds with parkinsonism and alphasynuclein genomic multiplications. Annals of neurology. 2004; 55:174-179. [PubMed: 14755720]

27. Jin H, Ishikawa K, Tsunemi T, Ishiguro T, Amino T, Mizusawa H. Analyses of copy number and mRNA expression level of the alpha-synuclein gene in multiple system atrophy. Journal of medical and dental sciences. 2008; 55:145-153. [PubMed: 19845160]

28. Ozawa T, Takano H, Onodera $\mathrm{O}$, et al. No mutation in the entire coding region of the alphasynuclein gene in pathologically confirmed cases of multiple system atrophy. Neuroscience letters. 1999; 270:110-112. [PubMed: 10462110]

29. Thal DR, Rub U, Orantes M, Braak H. Phases of A beta-deposition in the human brain and its relevance for the development of AD. Neurology. 2002; 58:1791-1800. [PubMed: 12084879]

30. Braak H, Braak E. Neuropathological stageing of Alzheimer-related changes. Acta Neuropathol. 1991; 82:239-259. [PubMed: 1759558]

31. Healy DG, Falchi M, O'Sullivan SS, et al. Phenotype, genotype, and worldwide genetic penetrance of LRRK2-associated Parkinson's disease: a case-control study. Lancet neurology. 2008; 7:583590. [PubMed: 18539534]

32. Farrer MJ, Stone JT, Lin CH, et al. Lrrk2 G2385R is an ancestral risk factor for Parkinson's disease in Asia. Parkinsonism \& related disorders. 2007; 13:89-92. [PubMed: 17222580]

33. Ozelius LJ, Senthil G, Saunders-Pullman R, et al. LRRK2 G2019S as a cause of Parkinson's disease in Ashkenazi Jews. N Engl J Med. 2006; 354:424-425. [PubMed: 16436782]

34. Gilks WP, Abou-Sleiman PM, Gandhi S, et al. A common LRRK2 mutation in idiopathic Parkinson's disease. Lancet. 2005; 365:415-416. [PubMed: 15680457]

35. Gaig C, Ezquerra M, Marti MJ, et al. Screening for the LRRK2 G2019S and codon-1441 mutations in a pathological series of parkinsonian syndromes and frontotemporal lobar degeneration. $\mathrm{J}$ Neurol Sci. 2008; 270:94-98. [PubMed: 18353371]

36. Gaig C, Marti MJ, Ezquerra M, Rey MJ, Cardozo A, Tolosa E. G2019S LRRK2 mutation causing Parkinson's disease without Lewy bodies. J Neurol Neurosurg Psychiatry. 2007; 78:626-628. [PubMed: 17210620]

37. Rajput A, Dickson DW, Robinson CA, et al. Parkinsonism, Lrrk2 G2019S, and tau neuropathology. Neurology. 2006; 67:1506-1508. [PubMed: 17060589]

38. Ross OA, Toft M, Whittle AJ, et al. Lrrk2 and Lewy body disease. Ann Neurol. 2006; 59:388-393. [PubMed: 16437559]

39. Giasson BI, Covy JP, Bonini NM, et al. Biochemical and pathological characterization of Lrrk2. Ann Neurol. 2006; 59:315-322. [PubMed: 16437584]

40. Gomez A, Ferrer I. Involvement of the cerebral cortex in Parkinson disease linked with G2019S LRRK2 mutation without cognitive impairment. Acta Neuropathol. 2010; 120:155-167. [PubMed: 20232069]

41. Silveira-Moriyama L, Guedes LC, Kingsbury A, et al. Hyposmia in G2019S LRRK2-related parkinsonism: clinical and pathologic data. Neurology. 2008; 71:1021-1026. [PubMed: 18809839]

42. Dachsel JC, Ross OA, Mata IF, et al. Lrrk2 G2019S substitution in frontotemporal lobar degeneration with ubiquitin-immunoreactive neuronal inclusions. Acta Neuropathol. 2007; 113:601-606. [PubMed: 17151837]

43. Poulopoulos MCE, Vonsattel JP, Fahn J, Waters C, Cote L, Moskowitz C, Honig L, Clark LN, Marder KS, Alcalay RN. Clinical and pathological characteristics of LRRK2 G2019S patients with PD. J Mol Neurosci. 2011 in press.

44. Hasegawa K, Kowa H. Autosomal dominant familial Parkinson disease: older onset of age and good response to levodopa therapy. Eur Neurol. 1997; 38(Suppl 1):39-43. [PubMed: 9276200]

45. Hasegawa K, Stoessl AJ, Yokoyama T, Kowa H, Wszolek ZK, Yagishita S. Familial parkinsonism: study of original Sagamihara PARK8 (I2020T) kindred with variable clinicopathologic outcomes. Parkinsonism Relat Disord. 2009; 15:300-306. [PubMed: 18804399]

46. Zimprich A, Biskup S, Leitner P, et al. Mutations in LRRK2 cause autosomal-dominant parkinsonism with pleomorphic pathology. Neuron. 2004; 44:601-607. [PubMed: 15541309] 
47. Wszolek ZK, Pfeiffer RF, Tsuboi Y, et al. Autosomal dominant parkinsonism associated with variable synuclein and tau pathology. Neurology. 2004; 62:1619-1622. [PubMed: 15136696]

48. Khan NL, Jain S, Lynch JM, et al. Mutations in the gene LRRK2 encoding dardarin (PARK8) cause familial Parkinson's disease: clinical, pathological, olfactory and functional imaging and genetic data. Brain : a journal of neurology. 2005; 128:2786-2796. [PubMed: 16272164]

49. Marti-Masso JF, Ruiz-Martinez J, Bolano MJ, et al. Neuropathology of Parkinson's disease with the R1441G mutation in LRRK2. Mov Disord. 2009; 24:1998-2001. [PubMed: 19735093]

50. Giordana MT, D'Agostino C, Albani G, et al. Neuropathology of Parkinson's disease associated with the LRRK2 Ile1371Val mutation. Mov Disord. 2007; 22:275-278. [PubMed: 17149743]

51. Covy JP, Yuan W, Waxman EA, Hurtig HI, Van Deerlin VM, Giasson BI. Clinical and pathological characteristics of patients with leucine-rich repeat kinase-2 mutations. Mov Disord. 2009; 24:32-39. [PubMed: 19006185]

52. Puschmann A, Englund E, Ross OA, et al. First neuropathological description of a patient with Parkinson's disease and LRRK2 p.N1437H mutation. Parkinsonism Relat Disord. 2011

53. Clark LN, Kisselev S, Park N, et al. Mutations in the Parkinson's disease genes, Leucine Rich Repeat Kinase 2 (LRRK2) and Glucocerebrosidase (GBA), are not associated with essential tremor. Parkinsonism \& related disorders. 2010; 16:132-135. [PubMed: 19527940]

54. Ross OA, Whittle AJ, Cobb SA, et al. Lrrk2 R1441 substitution and progressive supranuclear palsy. Neuropathology and applied neurobiology. 2006; 32:23-25. [PubMed: 16409550]

55. Wider C, Dickson DW, Wszolek ZK. Leucine-rich repeat kinase 2 gene-associated disease: redefining genotype-phenotype correlation. Neurodegener Dis. 2010; 7:175-179. [PubMed: 20197701]

56. Lucking CB, Durr A, Bonifati V, et al. Association between early-onset Parkinson's disease and mutations in the parkin gene. N Engl J Med. 2000; 342:1560-1567. [PubMed: 10824074]

57. Ishikawa A, Tsuji S. Clinical analysis of 17 patients in 12 Japanese families with autosomalrecessive type juvenile parkinsonism. Neurology. 1996; 47:160-166. [PubMed: 8710071]

58. Lohmann E, Periquet M, Bonifati V, et al. How much phenotypic variation can be attributed to parkin genotype? Ann Neurol. 2003; 54:176-185. [PubMed: 12891670]

59. Alcalay RN, Caccappolo E, Mejia-Santana H, et al. Frequency of known mutations in early-onset Parkinson disease: implication for genetic counseling: the consortium on risk for early onset Parkinson disease study. Archives of neurology. 2010; 67:1116-1122. [PubMed: 20837857]

60. Marder KS, Tang MX, Mejia-Santana H, et al. Predictors of parkin mutations in early-onset Parkinson disease: the consortium on risk for early-onset Parkinson disease study. Arch Neurol. 2010; 67:731-738. [PubMed: 20558392]

61. Pankratz N, Kissell DK, Pauciulo MW, et al. Parkin dosage mutations have greater pathogenicity in familial PD than simple sequence mutations. Neurology. 2009; 73:279-286. [PubMed: 19636047]

62. Matsumine H, Saito M, Shimoda-Matsubayashi S, et al. Localization of a gene for an autosomal recessive form of juvenile Parkinsonism to chromosome 6q25.2-27. American journal of human genetics. 1997; 60:588-596. [PubMed: 9042918]

63. Takahashi H, Ohama E, Suzuki S, et al. Familial juvenile parkinsonism: clinical and pathologic study in a family. Neurology. 1994; 44:437-441. [PubMed: 8145912]

64. Farrer M, Chan P, Chen R, et al. Lewy bodies and parkinsonism in families with parkin mutations. Ann Neurol. 2001; 50:293-300. [PubMed: 11558785]

65. Mori H, Kondo T, Yokochi M, et al. Pathologic and biochemical studies of juvenile parkinsonism linked to chromosome 6q. Neurology. 1998; 51:890-892. [PubMed: 9748052]

66. Sasaki S, Shirata A, Yamane K, Iwata M. Involvement of spinal motor neurons in parkin-positive autosomal recessive juvenile parkinsonism. Neuropathology : official journal of the Japanese Society of Neuropathology. 2008; 28:74-80. [PubMed: 18031467]

67. Yamamura Y, Kuzuhara S, Kondo K, et al. Clinical, pathologic and genetic studies on autosomal recessive early-onset parkinsonism with diurnal fluctuation. Parkinsonism Relat Disord. 1998; 4:65-72. [PubMed: 18591091] 
68. Hayashi S, Wakabayashi K, Ishikawa A, et al. An autopsy case of autosomal-recessive juvenile parkinsonism with a homozygous exon 4 deletion in the parkin gene. Mov Disord. 2000; 15:884888. [PubMed: 11009195]

69. van de Warrenburg BP, Lammens M, Lucking CB, et al. Clinical and pathologic abnormalities in a family with parkinsonism and parkin gene mutations. Neurology. 2001; 56:555-557. [PubMed: 11222808]

70. Mori H, Hattori N, Mizuno Y. Genotype-phenotype correlation: familial Parkinson disease. Neuropathology : official journal of the Japanese Society of Neuropathology. 2003; 23:90-94. [PubMed: 12722931]

71. Gouider-Khouja N, Larnaout A, Amouri R, et al. Autosomal recessive parkinsonism linked to parkin gene in a Tunisian family. Clinical, genetic and pathological study. Parkinsonism Relat Disord. 2003; 9:247-251. [PubMed: 12781588]

72. Pramstaller PP, Schlossmacher MG, Jacques TS, et al. Lewy body Parkinson's disease in a large pedigree with 77 Parkin mutation carriers. Ann Neurol. 2005; 58:411-422. [PubMed: 16130111]

73. Sasaki S, Shirata A, Yamane K, Iwata M. Parkin-positive autosomal recessive juvenile Parkinsonism with alpha-synuclein-positive inclusions. Neurology. 2004; 63:678-682. [PubMed: 15326242]

74. Morales B, Martinez A, Gonzalo I, et al. Steele-Richardson-Olszewski syndrome in a patient with a single C212Y mutation in the parkin protein. Mov Disord. 2002; 17:1374-1380. [PubMed: 12465088]

75. Alcalay RN, Siderowf A, Ottman R, et al. Olfaction in Parkin heterozygotes and compound heterozygotes: the CORE-PD study. Neurology. 2011; 76:319-326. [PubMed: 21205674]

76. Rogaeva E, Johnson J, Lang AE, et al. Analysis of the PINK1 gene in a large cohort of cases with Parkinson disease. Arch Neurol. 2004; 61:1898-1904. [PubMed: 15596610]

77. Steinlechner S, Stahlberg J, Volkel B, et al. Co-occurrence of affective and schizophrenia spectrum disorders with PINK1 mutations. J Neurol Neurosurg Psychiatry. 2007; 78:532-535. [PubMed: 17202228]

78. Samaranch L, Lorenzo-Betancor O, Arbelo JM, et al. PINK1-linked parkinsonism is associated with Lewy body pathology. Brain : a journal of neurology. 2010; 133:1128-1142. [PubMed: 20356854]

79. Khan NL, Valente EM, Bentivoglio AR, et al. Clinical and subclinical dopaminergic dysfunction in PARK6-linked parkinsonism: an 18F-dopa PET study. Annals of neurology. 2002; 52:849-853. [PubMed: 12447943]

80. Gandhi S, Muqit MM, Stanyer L, et al. PINK1 protein in normal human brain and Parkinson's disease. Brain : a journal of neurology. 2006; 129:1720-1731. [PubMed: 16702191]

81. van Duijn CM, Dekker MC, Bonifati V, et al. Park7, a novel locus for autosomal recessive earlyonset parkinsonism, on chromosome 1p36. Am J Hum Genet. 2001; 69:629-634. [PubMed: 11462174]

82. Bonifati V, Rizzu P, van Baren MJ, et al. Mutations in the DJ-1 gene associated with autosomal recessive early-onset parkinsonism. Science. 2003; 299:256-259. [PubMed: 12446870]

83. Lockhart PJ, Lincoln S, Hulihan M, et al. DJ-1 mutations are a rare cause of recessively inherited early onset parkinsonism mediated by loss of protein function. J Med Genet. 2004; 41:e22. [PubMed: 14985393]

84. Annesi G, Savettieri G, Pugliese P, et al. DJ-1 mutations and parkinsonism-dementia-amyotrophic lateral sclerosis complex. Ann Neurol. 2005; 58:803-807. [PubMed: 16240358]

85. Hruska KS, LaMarca ME, Scott CR, Sidransky E. Gaucher disease: mutation and polymorphism spectrum in the glucocerebrosidase gene (GBA). Human mutation. 2008; 29:567-583. [PubMed: 18338393]

86. Tayebi N, Callahan M, Madike V, et al. Gaucher disease and parkinsonism: a phenotypic and genotypic characterization. Molecular genetics and metabolism. 2001; 73:313-321. [PubMed: 11509013]

87. Clark LN, Nicolai A, Afridi S, et al. Pilot association study of the beta-glucocerebrosidase N370S allele and Parkinson's disease in subjects of Jewish ethnicity. Movement disorders : official journal of the Movement Disorder Society. 2005; 20:100-103. [PubMed: 15517591] 
88. Clark LN, Ross BM, Wang Y, et al. Mutations in the glucocerebrosidase gene are associated with early-onset Parkinson disease. Neurology. 2007; 69:1270-1277. [PubMed: 17875915]

89. Clark LN, Kartsaklis LA, Wolf Gilbert R, et al. Association of glucocerebrosidase mutations with dementia with lewy bodies. Archives of neurology. 2009; 66:578-583. [PubMed: 19433657]

90. Tayebi N, Walker J, Stubblefield B, et al. Gaucher disease with parkinsonian manifestations: does glucocerebrosidase deficiency contribute to a vulnerability to parkinsonism? Molecular genetics and metabolism. 2003; 79:104-109. [PubMed: 12809640]

91. Wong K, Sidransky E, Verma A, et al. Neuropathology provides clues to the pathophysiology of Gaucher disease. Molecular genetics and metabolism. 2004; 82:192-207. [PubMed: 15234332]

92. Goker-Alpan O, Stubblefield BK, Giasson BI, Sidransky E. Glucocerebrosidase is present in alphasynuclein inclusions in Lewy body disorders. Acta neuropathologica. 2010; 120:641-649. [PubMed: 20838799]

93. Lwin A, Orvisky E, Goker-Alpan O, LaMarca ME, Sidransky E. Glucocerebrosidase mutations in subjects with parkinsonism. Molecular genetics and metabolism. 2004; 81:70-73. [PubMed: 14728994]

94. Nishioka K, Ross OA, Vilarino-Guell C, et al. Glucocerebrosidase mutations in diffuse Lewy body disease. Parkinsonism \& related disorders. 2011; 17:55-57. [PubMed: 20971030]

95. Farrer MJ, Williams LN, Algom AA, et al. Glucosidase-beta variations and Lewy body disorders. Parkinsonism \& related disorders. 2009; 15:414-416. [PubMed: 18829375]

96. Neumann J, Bras J, Deas E, et al. Glucocerebrosidase mutations in clinical and pathologically proven Parkinson's disease. Brain : a journal of neurology. 2009; 132:1783-1794. [PubMed: 19286695]

97. Goker-Alpan O, Giasson BI, Eblan MJ, et al. Glucocerebrosidase mutations are an important risk factor for Lewy body disorders. Neurology. 2006; 67:908-910. [PubMed: 16790605]

98. Eblan MJ, Walker JM, Sidransky E. The glucocerebrosidase gene and Parkinson's disease in Ashkenazi Jews. The New England journal of medicine. 2005; 352:728-731. author reply-31. [PubMed: 15716572]

99. Mata IF, Samii A, Schneer SH, et al. Glucocerebrosidase gene mutations: a risk factor for Lewy body disorders. Archives of neurology. 2008; 65:379-382. [PubMed: 18332251]

100. Segarane B, Li A, Paudel R, et al. Glucocerebrosidase mutations in 108 neuropathologically confirmed cases of multiple system atrophy. Neurology. 2009; 72:1185-1186. [PubMed: 19332698]

101. Parkkinen L, Neumann J, O'Sullivan SS, et al. Glucocerebrosidase mutations do not cause increased Lewy body pathology in Parkinson's disease. Molecular genetics and metabolism. 2011

102. Lesage S, Anheim M, Condroyer C, et al. Large-scale screening of the Gaucher's disease-related glucocerebrosidase gene in Europeans with Parkinson's disease. Human molecular genetics. 2011; 20:202-210. [PubMed: 20947659]

103. Nichols WC, Pankratz N, Marek DK, et al. Mutations in GBA are associated with familial Parkinson disease susceptibility and age at onset. Neurology. 2009; 72:310-316. [PubMed: 18987351]

104. McKeith IG, Dickson DW, Lowe J, et al. Diagnosis and management of dementia with Lewy bodies: third report of the DLB Consortium. Neurology. 2005; 65:1863-1872. [PubMed: 16237129]

105. Klein C, Chuang R, Marras C, Lang AE. The curious case of phenocopies in families with genetic Parkinson's disease. Mov Disord. 2011

106. Parkkinen L, Pirttila T, Alafuzoff I. Applicability of current staging/categorization of alphasynuclein pathology and their clinical relevance. Acta neuropathologica. 2008; 115:399-407. [PubMed: 18297293]

107. Galpern WR, Lang AE. Interface between tauopathies and synucleinopathies: a tale of two proteins. Annals of neurology. 2006; 59:449-458. [PubMed: 16489609]

108. Santpere G, Ferrer I. LRRK2 and neurodegeneration. Acta neuropathologica. 2009; 117:227-246. [PubMed: 19142648]

109. Nakashima-Yasuda H, Uryu K, Robinson J, et al. Co-morbidity of TDP-43 proteinopathy in Lewy body related diseases. Acta Neuropathol. 2007; 114:221-229. [PubMed: 17653732] 
110. Hughes AJ, Daniel SE, Kilford L, Lees AJ. Accuracy of Clinical-Diagnosis of Idiopathic Parkinsons-Disease - a Clinicopathological Study of 100 Cases. J Neurol Neurosur Ps. 1992; 55:181-184.

111. Valente EM, Bentivoglio AR, Dixon PH, et al. Localization of a novel locus for autosomal recessive early-onset parkinsonism, PARK6, on human chromosome 1p35-p36. Am J Hum Genet. 2001; 68:895-900. [PubMed: 11254447] 


\begin{tabular}{|c|c|c|c|c|c|c|c|c|c|c|c|c|}
\hline 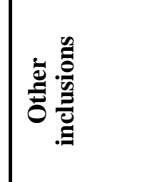 & & & 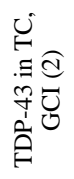 & $\overrightarrow{0}$ & & & & $\vec{~}$ & ' & & $\vec{U}$ & \\
\hline 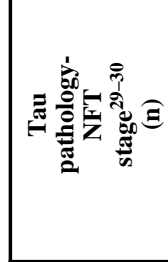 & 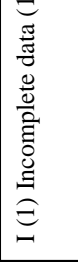 & $\underset{1}{\widehat{d}}$ & $\underbrace{Ð}_{Z \geq}$ & 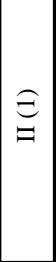 & $\bigodot_{1}$ & 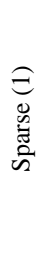 & $\underset{1}{Ð}$ & $\bigoplus_{1}$ & 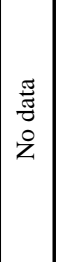 & $\widehat{\widehat{d}}$ & $\Xi$ & $\underset{\Xi}{\Xi}$ \\
\hline 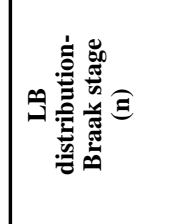 & 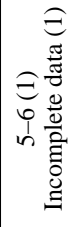 & $\begin{array}{l}\widehat{d} \\
0 \\
i \\
n\end{array}$ & 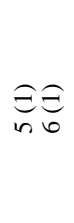 & $\underset{छ}{\Xi}$ & $\widehat{\Xi}$ & 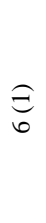 & $\begin{array}{l}\text { 委 } \\
\vdots \\
\text { in }\end{array}$ & $\begin{array}{l}\hat{\sigma} \\
0\end{array}$ & $\widehat{్}$ & $\begin{array}{l}\text { d } \\
0 \\
i \\
\text { in }\end{array}$ & $\begin{array}{l}\widehat{\Xi} \\
0 \\
\text { in }\end{array}$ & $\begin{array}{l}\widehat{\Xi} \\
\vdots \\
i\end{array}$ \\
\hline 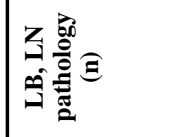 & $\underset{+}{\widehat{d}}$ & $\begin{array}{l}\widehat{d} \\
+\end{array}$ & $\underset{+}{\widehat{d}}$ & $\underset{+}{Ð}$ & $\underset{+}{Ð}$ & $\underset{+}{Ð}$ & $\underset{+}{\stackrel{f}{+}}$ & $\begin{array}{l}\Xi \\
+\end{array}$ & $\underset{+}{Ð}$ & $\underset{+}{\widehat{d}}$ & $\underset{+}{\ominus}$ & $\underset{+}{Ð}$ \\
\hline 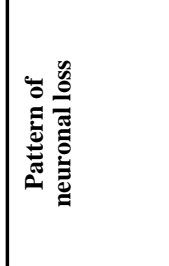 & \begin{tabular}{|l}
$u$ \\
\\
$z$ \\
$n$
\end{tabular} & 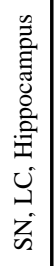 & 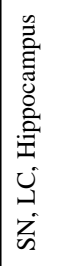 & \begin{tabular}{l|}
$\vec{z}$ \\
0 \\
0 \\
\\
$z$ \\
$m$
\end{tabular} & 崇 & 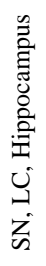 & 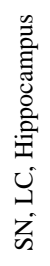 & 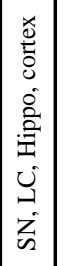 & 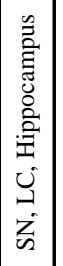 & 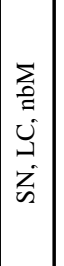 & 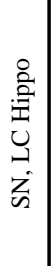 & 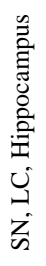 \\
\hline 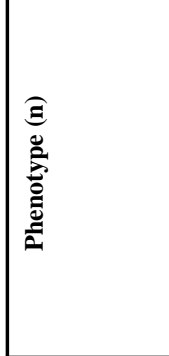 & 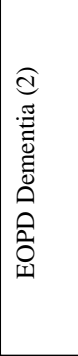 & 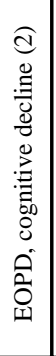 & 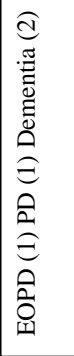 & 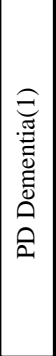 & 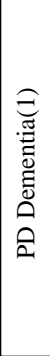 & 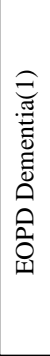 & 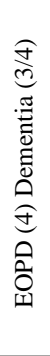 & 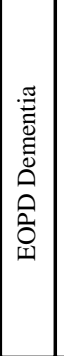 & 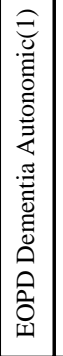 & 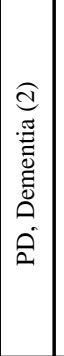 & 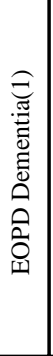 & 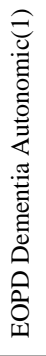 \\
\hline 产 & 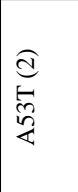 & 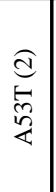 & $\begin{array}{l}\widehat{a} \\
\stackrel{2}{\infty} \\
\stackrel{2}{\&}\end{array}$ & $\begin{array}{l}\hat{\Xi} \\
\hat{\sigma} \\
\tilde{c} \\
\dot{\alpha}\end{array}$ & 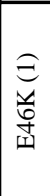 & 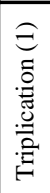 & 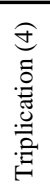 & 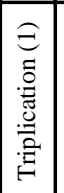 & 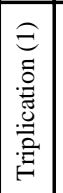 & 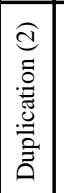 & 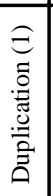 & 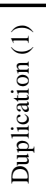 \\
\hline 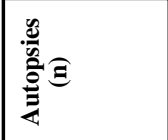 & 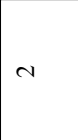 & $\sim$ & $\sim$ & - & - & - & $\nabla$ & - & - & $\sim$ & - & - \\
\hline : & 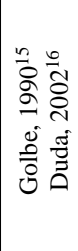 & 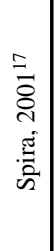 & 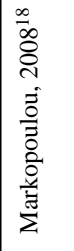 & 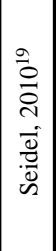 & 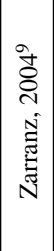 & 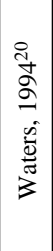 & 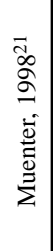 & 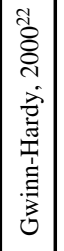 & 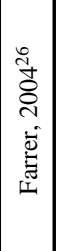 & 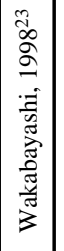 & 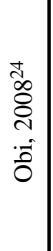 & 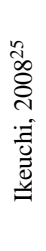 \\
\hline
\end{tabular}




\begin{tabular}{|c|c|c|c|c|c|c|c|c|c|c|c|c|c|c|c|c|}
\hline 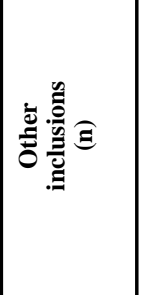 & & & 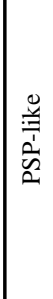 & & & 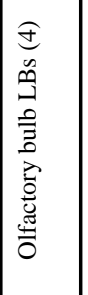 & 筁 & & $\begin{array}{l}E \\
\bar{U} \\
0\end{array}$ & 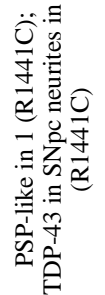 & 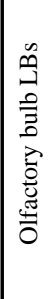 & 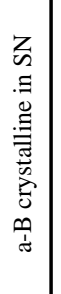 & & & & 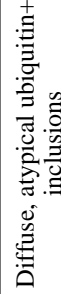 \\
\hline 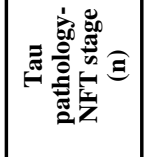 & 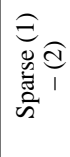 & 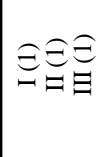 & $\begin{array}{l}E \\
\geq\end{array}$ & $\begin{array}{l}\hat{q}=90 \\
1=0\end{array}$ & 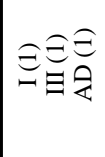 & $\stackrel{\oplus}{=}$ & $\begin{array}{l}\equiv \\
1\end{array}$ & 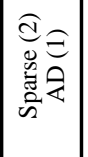 & $\frac{\widehat{\infty}}{1}$ & 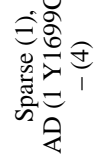 & $\varrho$ & $\varrho$ & 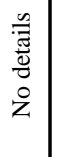 & $E$ & $\begin{array}{l}E \\
=\Xi\end{array}$ & $\begin{array}{l}\text { 总 } \\
\text { 童 }\end{array}$ \\
\hline 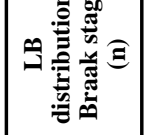 & $\begin{array}{ll}\text { Eิ } \\
\text { ले }\end{array}$ & 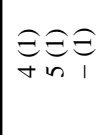 & ' & $\begin{array}{l}\text { fỗ } \\
\text { my }\end{array}$ & 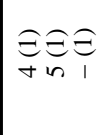 & 跔 & $\begin{array}{l}\underset{1}{1} \\
1\end{array}$ & 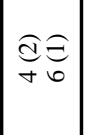 & $\begin{array}{l}E E \\
1 \mathrm{~m}\end{array}$ & $\begin{array}{ll}\text { EEf } \\
+0.0\end{array}$ & $\vec{m}_{\text {en }}$ & ' & 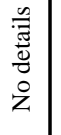 & E & $\frac{y}{y}$ & $\bar{z}$ \\
\hline 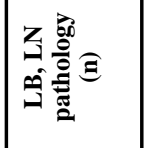 & $\begin{array}{l}\hat{0} \\
+\end{array}$ & $\mid \begin{array}{l}a \\
a \\
+1\end{array}$ & $\overbrace{1}$ & $\begin{array}{l}\frac{0}{0} \\
+1\end{array}$ & $\begin{array}{l}a \widehat{a} \\
+1\end{array}$ & 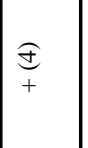 & $\begin{array}{l}\varrho \\
1\end{array}$ & 辛 & $\begin{array}{l}E E \\
1+\end{array}$ & 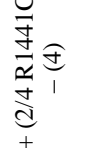 & $\begin{array}{l}\varrho \\
+\end{array}$ & $\bigodot_{1}$ & $\underset{+}{\widehat{\Xi}}$ & $\begin{array}{l}E \\
+\end{array}$ & $\begin{array}{l}\frac{1}{4} \\
+\end{array}$ & + \\
\hline 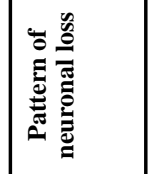 & 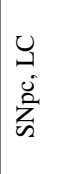 & 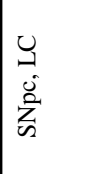 & 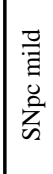 & 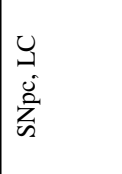 & 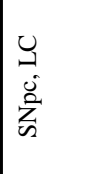 & 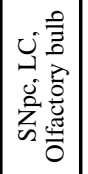 & 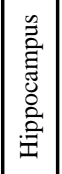 & 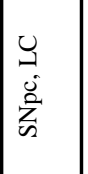 & 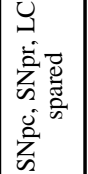 & 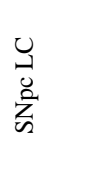 & 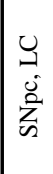 & 訔 & 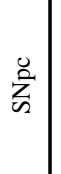 & & & 密 \\
\hline 音 & $\begin{array}{l}\hat{2} \\
\hat{2}\end{array}$ & $\begin{array}{l}\hat{0} \\
\hat{2} \\
\hat{2}\end{array}$ & $\begin{array}{l}\Xi \\
\varrho \\
\hat{2}\end{array}$ & 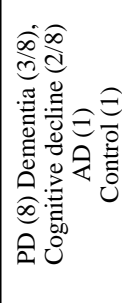 & 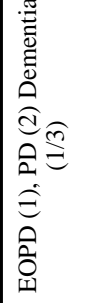 & $\begin{array}{l}\text { f } \\
2\end{array}$ & 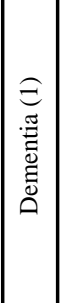 & 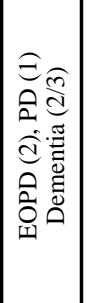 & $\frac{a}{a}$ & $\begin{array}{l}0 \\
0 \\
2\end{array}$ & $\begin{array}{l}\hat{\theta} \\
\hat{2}\end{array}$ & $\stackrel{\Xi}{\hat{2}}$ & 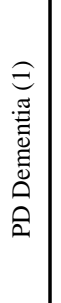 & 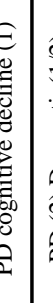 & & 10 \\
\hline 产 & 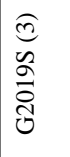 & 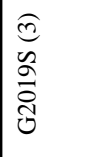 & 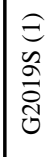 & 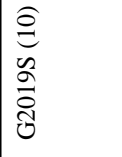 & 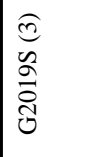 & 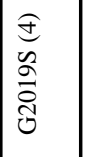 & $\begin{array}{l}E \\
0 \\
o \\
\bar{े} \\
0\end{array}$ & 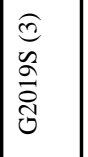 & 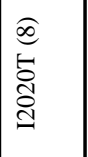 & 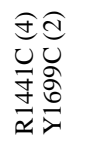 & 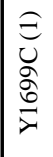 & 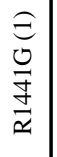 & $\begin{array}{l}E \\
\frac{\approx}{\frac{7}{\varkappa}}\end{array}$ & E & 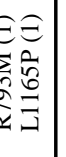 & $\begin{array}{l}\text { E } \\
\text { 章 } \\
\frac{9}{\bar{z}} \\
\end{array}$ \\
\hline 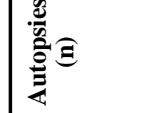 & $m$ & $m$ & - & $\cong$ & $m$ & + & - & $m$ & $\infty$ & 0 & - & - & - & - & $\mathrm{v}$ & - \\
\hline 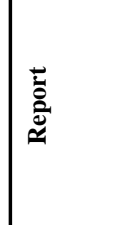 & 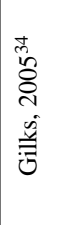 & 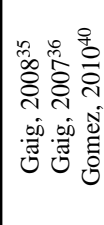 & 营 & 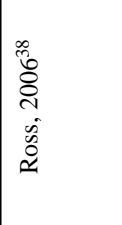 & 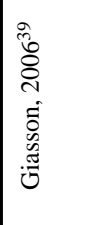 & 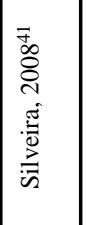 & 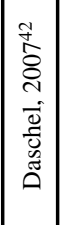 & 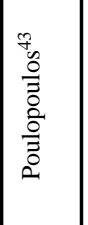 & 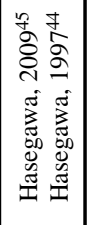 & 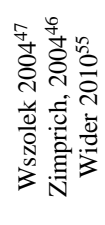 & 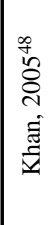 & 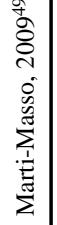 & 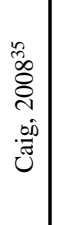 & 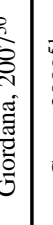 & 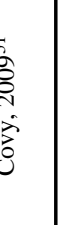 & 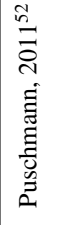 \\
\hline
\end{tabular}




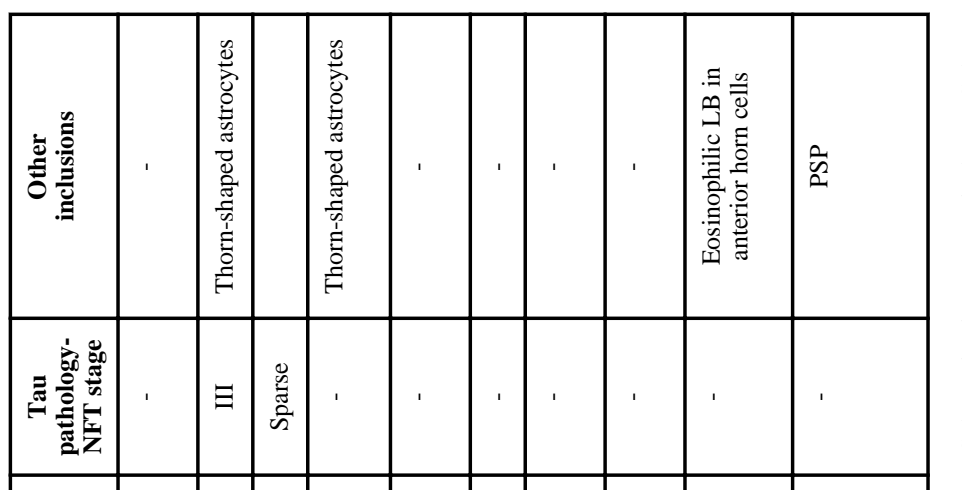

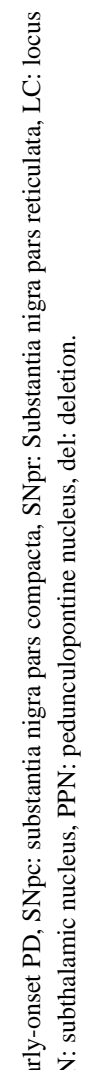

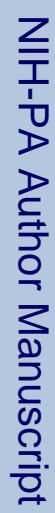

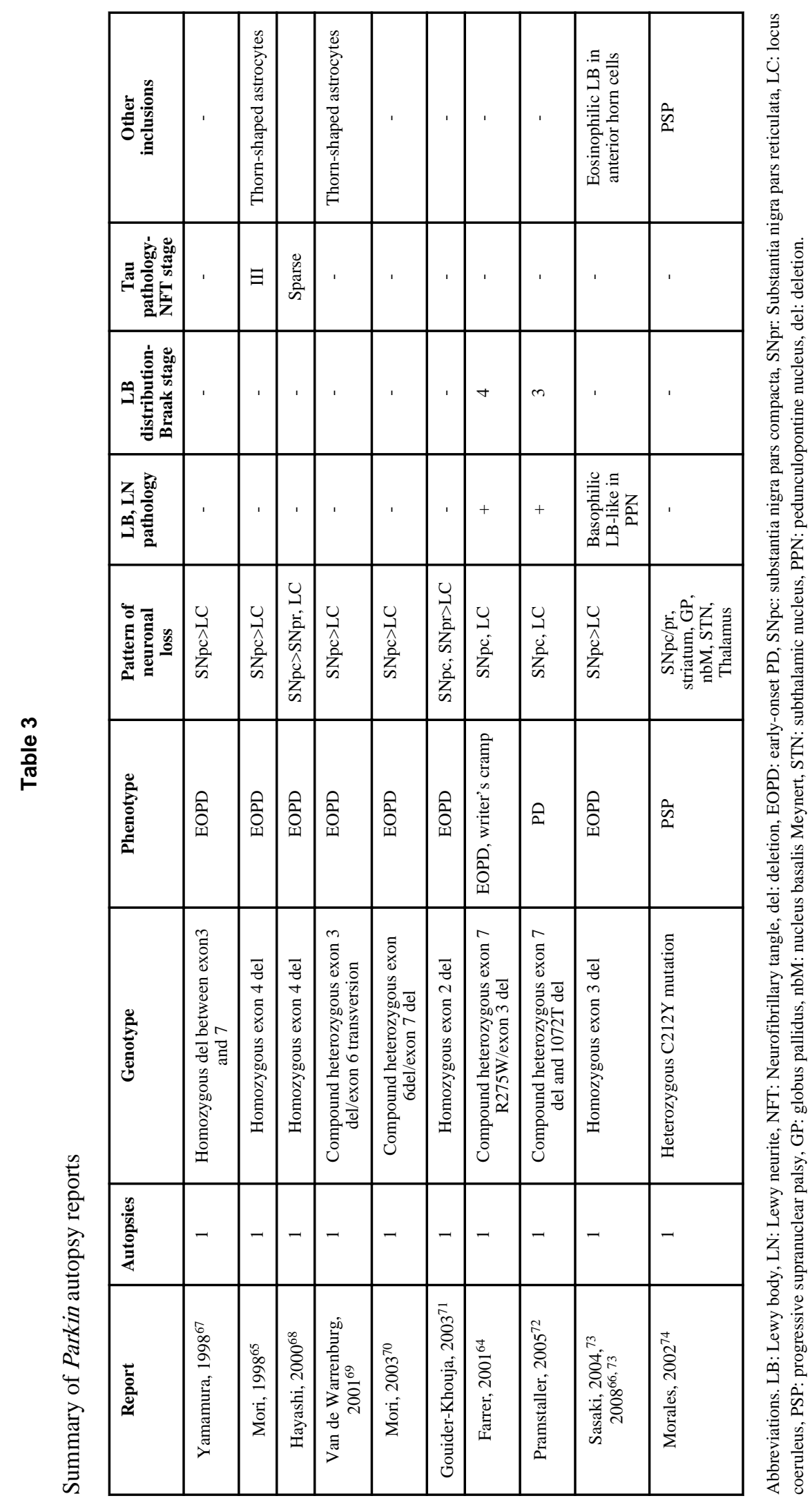




\begin{tabular}{|c|c|c|c|c|c|c|c|c|}
\hline 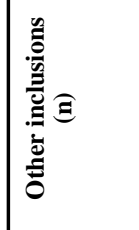 & 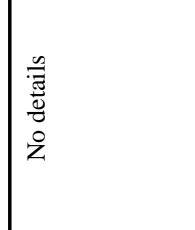 & 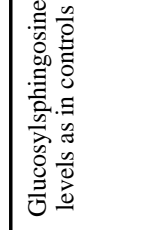 & 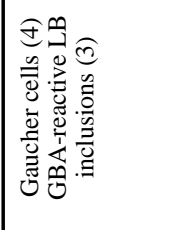 & 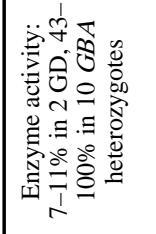 & 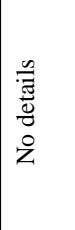 & 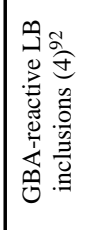 & 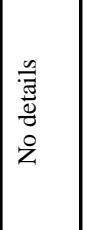 & 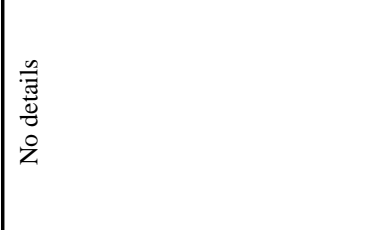 \\
\hline 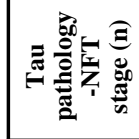 & $\stackrel{\widehat{a}}{\mid=}$ & 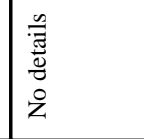 & 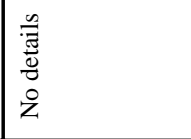 & 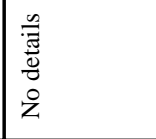 & 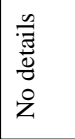 & \begin{tabular}{l}
$\hat{b}_{\widehat{O}}$ \\
\hdashline$\frac{1}{4}$
\end{tabular} & $\begin{array}{c}\Theta € \\
>=\end{array}$ & $\begin{array}{l}\hat{a} \\
\stackrel{8}{8}\end{array}$ \\
\hline 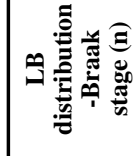 & $\begin{array}{l}E \\
E \\
0 \\
0 \\
n\end{array}$ & 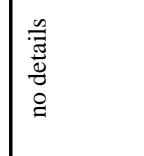 & 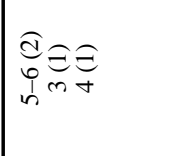 & 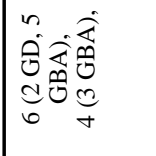 & 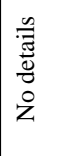 & 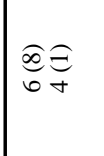 & a & 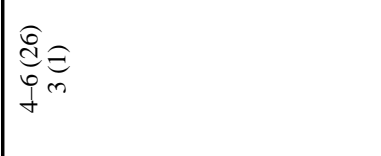 \\
\hline 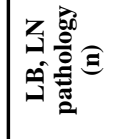 & $\underset{+}{E}$ & 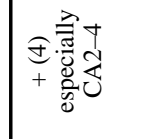 & 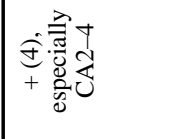 & 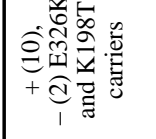 & $\frac{a}{+}$ & $\begin{array}{l}\sigma \\
+ \\
+\end{array}$ & $\frac{a}{+}$ & $\frac{a}{a}$ \\
\hline 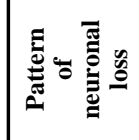 & 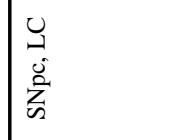 & 密 & 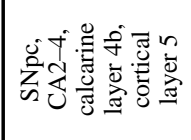 & 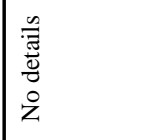 & 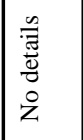 & 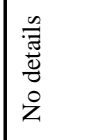 & 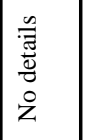 & 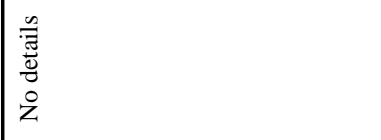 \\
\hline 产 & 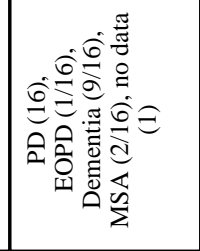 & 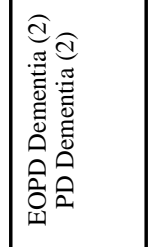 & 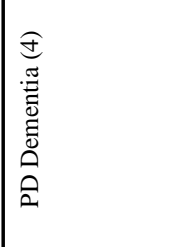 & 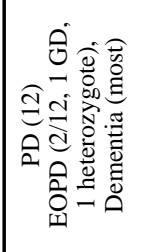 & $\begin{array}{l}\widehat{a} \\
\hat{a} \\
\hat{a}\end{array}$ & 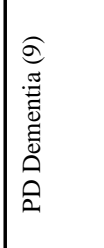 & 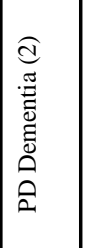 & 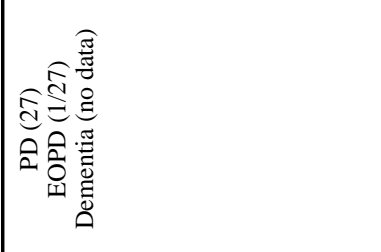 \\
\hline 产 & 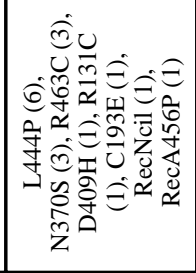 & 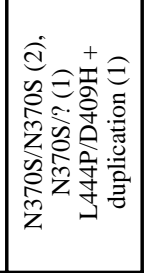 & 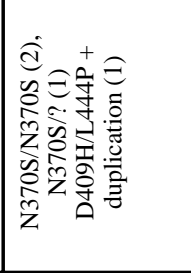 & 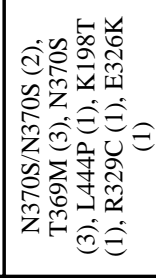 & 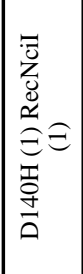 & 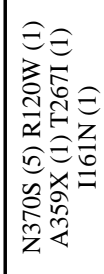 & 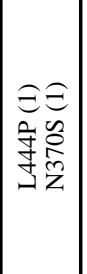 & 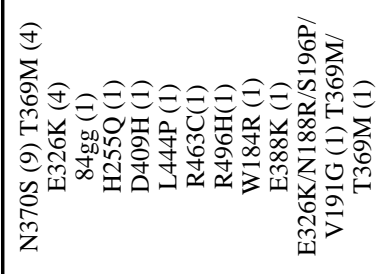 \\
\hline 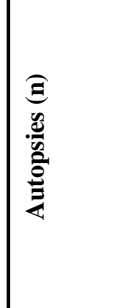 & 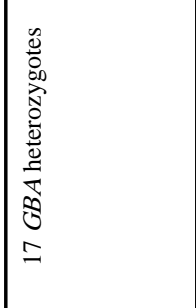 & $\begin{array}{l}\text { Oे } \\
\text { t }\end{array}$ & 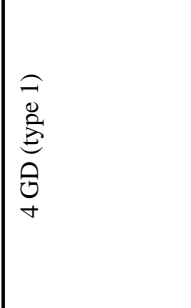 & 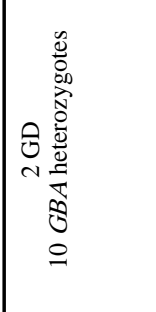 & 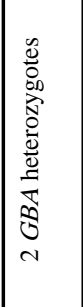 & 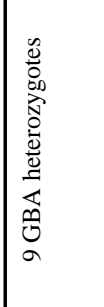 & 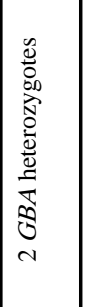 & 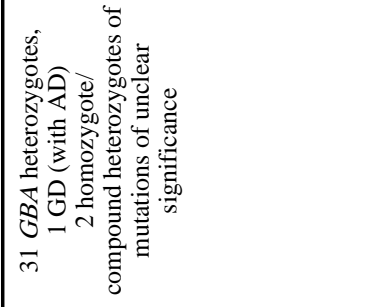 \\
\hline 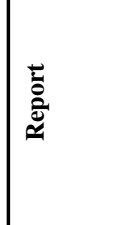 & 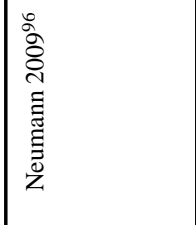 & 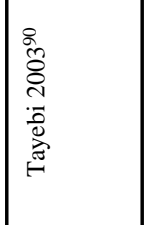 & 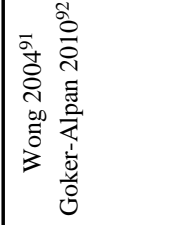 & $\mid$ & 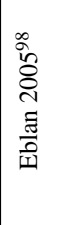 & 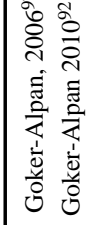 & 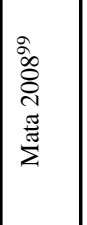 & 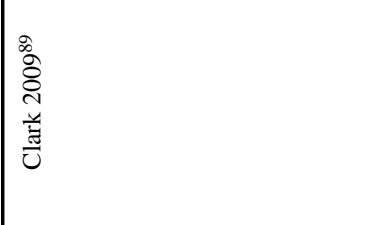 \\
\hline
\end{tabular}




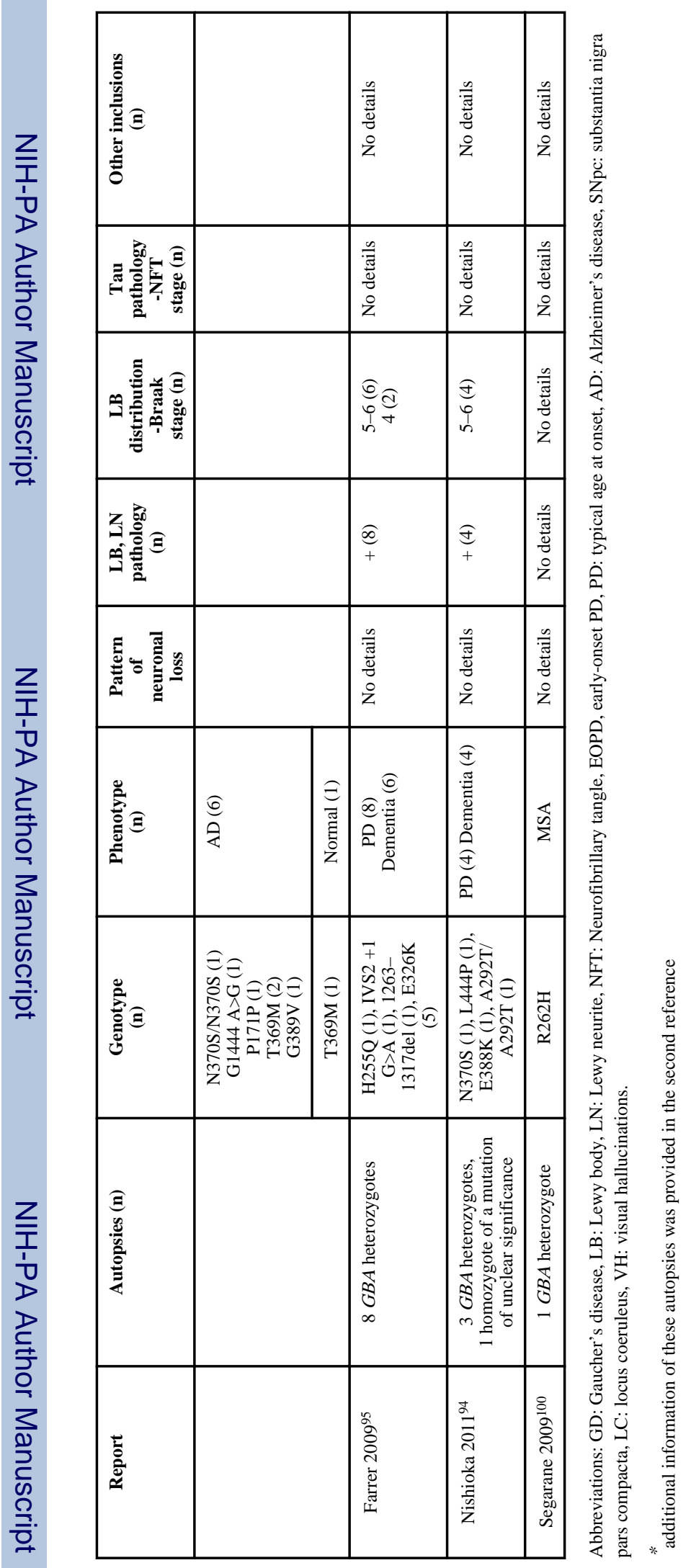

Mov Disord. Author manuscript; available in PMC 2013 June 01. 


\begin{tabular}{|c|c|c|c|c|c|c|c|c|}
\hline 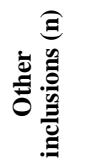 & 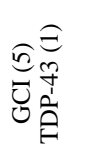 & 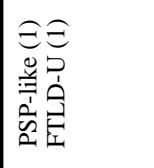 & 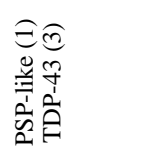 & 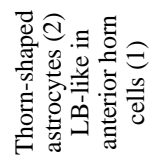 & & & 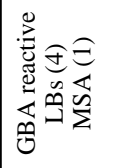 & 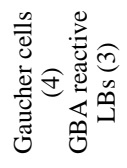 \\
\hline 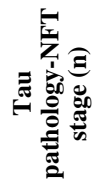 & 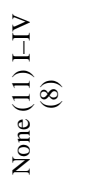 & 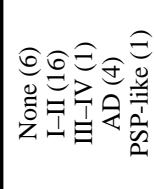 & 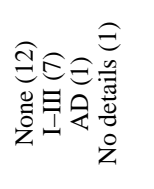 & $\underset{1}{E \infty}$ & & & 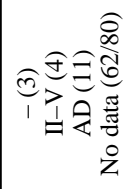 & $\begin{array}{l}\text { 㺃 } \\
\text { ¿̊z }\end{array}$ \\
\hline 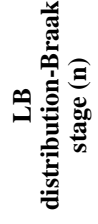 & 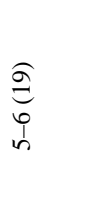 & 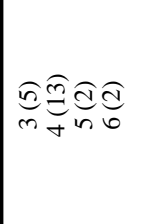 & 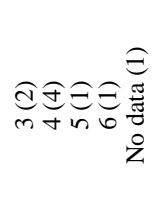 & $\begin{array}{l}\hat{d} \\
\vec{a} \\
\dot{m}\end{array}$ & $\underset{\exists}{\Xi}$ & & 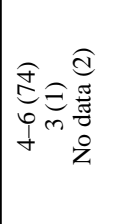 & 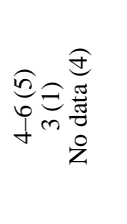 \\
\hline 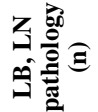 & $\underset{+}{\stackrel{Ð}{\rightleftarrows}}$ & $\begin{array}{l}\text { बृe } \\
+1\end{array}$ & 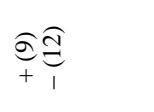 & $\begin{array}{l}\text { de } \\
+1\end{array}$ & + & & $\begin{array}{l}\text { EC } \\
\text { Sod } \\
+1\end{array}$ & $\underset{+}{\stackrel{Y}{0}}$ \\
\hline 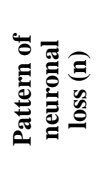 & 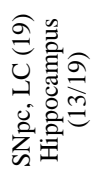 & 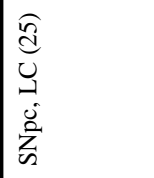 & 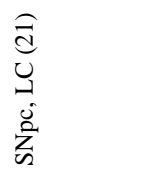 & 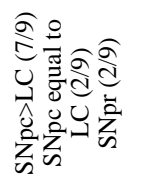 & 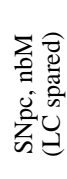 & & 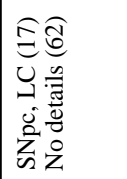 & 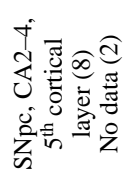 \\
\hline 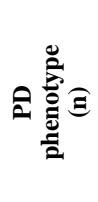 & 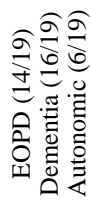 & 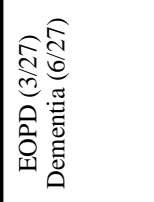 & 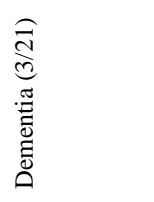 & 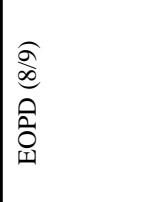 & 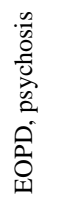 & & 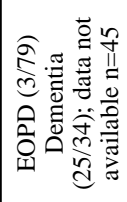 & 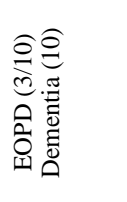 \\
\hline 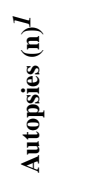 & 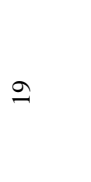 & 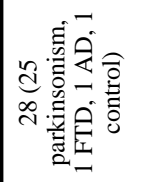 & $\vec{\sim}$ & $a$ & - & 0 & 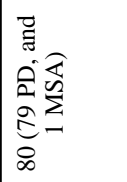 & 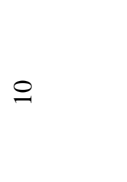 \\
\hline 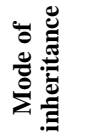 & \& & \& & & $\frac{a}{4}$ & 䎹 & 学 & & $\frac{\Omega}{4}$ \\
\hline 号 & $\begin{array}{l}\text { स̃ } \\
\frac{1}{\mathcal{Z}}\end{array}$ & 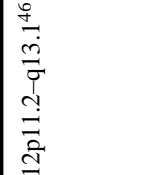 & & 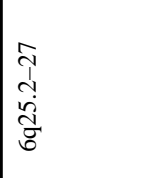 & 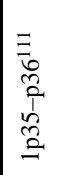 & \begin{tabular}{|l}
$\overrightarrow{\vec{s}_{0}}$ \\
$\cong$ \\
$=$ \\
$=$
\end{tabular} & $\frac{\infty}{\mathfrak{D}}$ & \\
\hline ڤँّ̃ & 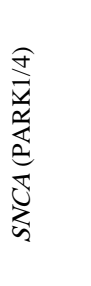 & 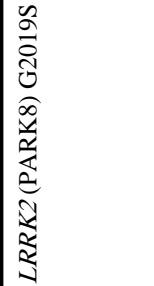 & 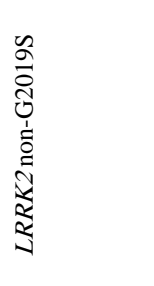 & 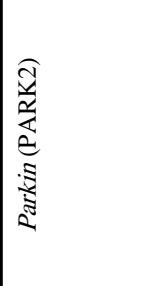 & 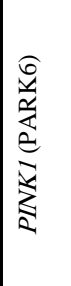 & 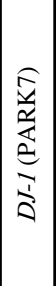 & 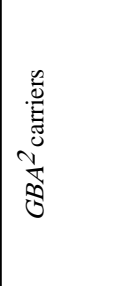 & है \\
\hline
\end{tabular}

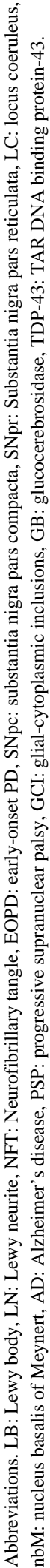

